\title{
Bioremediation of oil on shoreline environments: development of techniques and guidelines*
}

\author{
Kenneth Lee ${ }^{\dagger, 1}$ and Francois Xavier Merlin ${ }^{2}$ \\ ${ }^{1}$ Fisheries and Oceans, Maurice Lamontagne Institute, PO Box 1000, Mont-Joli, Quebec, \\ G5H 3Z4, Canada; ${ }^{2}$ Centre de documentation de recherche et $d$ 'experimentations sur les \\ pollutions accidentelles des eaux (CEDRE), B.P. 72, 29280 Plouzane, France
}

\begin{abstract}
Over the last 20 years, the development of operational procedures to accelerate the natural biodegradation rates of oil spilled on shoreline environments has been the focus of numerous research programs. As a result, bioremediation has been demonstrated to be an effective oil spill countermeasure for use in cobble, sand beach, salt marsh, and mudflat environments. Today, studies are directed towards improving the efficacy and evaluating the ecological impacts of available bioremediation agents and/or procedures. This review describes the latest developments in bioremediation strategies and their key success factors.
\end{abstract}

\section{INTRODUCTION}

Microbial degradation is a principal process in the elimination of petroleum pollutants from the environment [1]. Bacteria and fungi, with the capability to degrade a wide range of oil components, have been found to exist throughout the marine ecosystem [2,3]. Studies on the fate of petroleum following marine oil spills have shown that the natural rates of hydrocarbon biodegradation are usually limited by abiotic environmental factors [4]. However, given sufficient time, the petroleum hydrocarbons will be degraded. In consideration of this fact, over the last 20 years, numerous bioremediation strategies have been developed for use as an oil spill countermeasure. With the reported success of cleanup operations using bioremediation in Alaska, following the Exxon Valdez oil spill [4-7], and that of other controlled field trials [8-10], bioremediation is now considered as one the most promising oil spill countermeasures $[11,12]$. However, to be fully recognized as an operational oil-spill response technology, R\&D programs are now required to identify its benefits and limitations, and to provide guidance for its application. This review describes recent advances in oil spill bioremediation technologies, highlights new concepts under consideration, and identifies the principal factors to consider in the application of these technologies.

\section{DEVELOPMENT AND EVALUATION OF BIOREMEDIATION TECHNOLOGIES}

There are two main approaches to oil-spill bioremediation: [1] Bioaugmentation (seeding) involves the addition of oil-degrading bacteria to supplement the existing microbial population; and [2] Biostimulation involves the addition of nutrients or other growth-enhancing cosubstrates to stimulate the growth of indigenous oil degraders.

\section{Bioaugmentation}

Microbial ecologists have demonstrated that the number of oil-degrading bacteria within sediments [6,13-15], open waters [16,17] and sea ice [18] increased, following exposure to oil. Thus, there appears

\footnotetext{
*Pure Appl. Chem. 71(1) (1999). An issue of special reports reviewing oil spill countermeasures. $\dagger$ Correspondence: Kenneth Lee, Microbiology and Hydrocarbons, Habitat Management and Environmental Science, Laurentian Region,Maurice Lamontagne Institute, 850, route de la Mer, PO Box 1000, Mont-Joli, Québec, Canada G5H 3Z4. E-mail: leek@dfo-mpo.gc.ca
} 
to be little or no need to add microorganisms to oil contaminated ecosystems. Furthermore, recent studies have shown that the addition of a commercial mixture of oil-degrading marine bacteria [13] and/or enriched cultures of indigenous oil-degrading bacteria $[9,19]$ did not significantly enhance rates of oil biodegradation in the natural environment over that achieved by nutrient enrichment alone. Allochthonous microorganisms appear to be unable to compete with the natural microflora under changing environmental conditions $[9,13]$.

Despite the negative results of field trials, commercial vendors continue to promote bioremediation agents containing microbial additives. Sterile controls in shaker flask efficacy tests of commercial products containing microbial inocula demonstrated that indigenous oil-degrading populations performed most, if not all, of the biodegradative activity [20,21]. Any positive effects of the products, above that of nutrient addition, were attributed to a cometabolite or some other unknown factor present fortuitously within the product. The concept of developing a genetically engineered 'super-bug' to degrade crude oil singlehandedly is seriously flawed [22]. The metabolic potential required to deal with the diverse array of chemicals within a crude oil is considerable. Even if it were technically feasible to incorporate all the necessary genetic information into recombinant microorganisms, the burden of maintaining all of these genes is likely to be so great as to make the recombinant strains noncompetitive in the natural environment.

Most successes with biodegradation enhancements using allochthonous microbial cultures have been achieved when chemostats or fermentors were used to control conditions and/or reduce competition from indigenous microflora [23]. While commercial seed cultures may be useful in the treatment of specific compounds within crude oil that are relatively resistant to degradation and isolated spills in confined areas [24], they appear to be of little benefit for the treatment of the bulk of petroleum contaminants in the open environment. In summary, oil biodegradation within the marine environment does not appear to be limited by microbial inocula. Thus, further development of bioremediation agents that contain oildegrading bacteria as the only active ingredient, is difficult to justify.

\section{Biostimulation}

\section{Addition of nutrients}

Although the potential capability of indigenous microflora to degrade oil is a function of the physical and chemical properties of the seawater and oil, the environmental conditions, and the biota themselves, it is generally accepted that nutrient availability is the most common limiting factor [25]. Experimental studies have shown that fertilization with nitrogen and phosphorus offers great promise as a countermeasure to combat oil spills in the marine environment $[26,27]$ and the optimum ratios of carbon, nitrogen, and phosphorus have been defined [28]. However, fertilization as a bioremediation strategy within the marine environment, is presumed to be difficult, especially in open waters, where the concentrations of watersoluble nutrients would presumably decrease rapidly through dilution. To counter this problem, oleophilic nutrient formulations have been developed to retain optimal nutrient concentrations at the oil-water interface where biodegradation occurs [25,29]. Inipol EAP 22 (Elf Aquitaine, France) is an example of one of the most promising oleophilic nutrient formulations developed to date [30]. The product is a microemulsion mixture composed of urea in brine encapsulated in oleic acid as the external phase with lauryl-ether-phosphate as a surfactant. While Inipol EAP 22 has been used on cobble beaches contaminated by the Exxon Valdez spill in Alaska with success [6], it has been proven to be ineffective at other sites. For example, during field trials in a sand beach environment, a single application of the product was found to be ineffective in enhancing the natural biodegradation rates of residual condensate [13]. Failure of the bioremediation treatment was attributed to the rapid loss of nutrients and an acute toxic response by the natural microflora to 'unweathered' condensate. Similar losses of this oleophilic nutrient from oiled sediments have been subsequently observed in laboratory studies [31] and field trials [32].

In numerous field trials, the feasibility of adding inorganic nutrients on a periodic basis has been demonstrated as a means of sustaining elevated nutrient concentrations within the sediments for effective bioremediation $[9,33,34]$. Controlled studies suggest that optimum rates of degradation could be 
sustained by retaining high (renewable concentrations, approaching 1-2 $\mathrm{mg} \mathrm{N} / \mathrm{L}$ interstitial pore water) but nontoxic, levels of nutrients [8,9]. The advantages of inorganic agricultural fertilizers as bioremediation agents include low cost, availability, and ease of application.

By using a randomized block design with replicate $4 \times 9 \mathrm{~m}$ experimental plots, a recent study in Delaware Bay, USA, has provided statistical evidence that inorganic mineral nutrient additions (sodium nitrate and sodium tripolyphosphate) enhanced the removal of Bonny Light crude oil contaminating a sandy beach [9]. Biodegradation of selected components was tracked by GC/MS analysis with correction for abiotic removal by normalization to the conserved biomarker hopane. In terms of bioaugmentation, a significant difference was not observed between the plots treated with the inorganic nutrients alone and plots treated with the nutrients and an indigenous microbial inocula (mixed population of hydrocarbon degrading bacteria isolated from the field site). Although unexpectedly high rates of biodegradation were observed in the untreated plots due to elevated background nitrogen concentrations at the site, statistically significant differences between treated and untreated plots were observed in the biodegradation rates of total alkane and total aromatic hydrocarbons. First-order rate constants for the disappearance of individual hopane-normalized alkanes and PAHs were computed, and the patterns of loss were typical of biodegradation.

While elevated nutrient concentrations within the interstitial waters in shorelines can be maintained by periodic additions of nutrients, it is not the most practical operational strategy. Slow-release fertilizer formulations have now been developed to decrease the cost and effort associated with bioremediation treatment [35]. In addition, there is now a renewed interest in the advantages of having an organic carbon source within bioremediation agents to promote rapid bacterial growth [36]. This has lead to the recent development and testing of organic fertilizers comprised of fish meal, animal meal, and/or fish bone meal [37,38]. Theoretically, optimal nutrient concentrations can be maintained within oiled sediments for prolonged periods by the internal nutrient regeneration processes coupled with the degradation of these products. Furthermore, these organic nutrient formulations may also provide trace elements and other growth factors required by bacteria.

\section{Addition of oxygen and alternate electron acceptors}

Microbial oil degradation rates within sediments are very slow under anoxic conditions [4,34]. Sediment tilling has been evaluated as a bioremediation treatment to increase the penetration depth of oxygen and nutrient supplements [39]. Two international programs are currently underway to monitor the effectiveness of tilling and/or nutrient enrichment as a bioremediation strategy for sand-gravel (Svalbard Shoreline Field Trials - Norway) and mudflat (European Union Mesocosm Experiment- the Netherlands) environments. Use of chemical oxidants such as hydrogen, calcium and magnesium peroxides to alleviate oxygen deficiency within sediments is now also being considered. While commercial forms of these products have been used in terrestrial environments for groundwater remediation, their application in the marine environment has not been addressed in detail.

Although carbon transformations by aerobic microorganisms are inhibited in many fine sediment/ wetland environments, facultative and obligate anaerobes become active in anoxic environments and will degrade organic compounds [40]. Carbon transfer processes in anoxic environments include fermentation, nitrate reduction, denitrification, and sulfate reduction [41]. Except for fermentation in which the organic compound itself acts as the terminal electron acceptor, these processes require an inorganic oxidant (e.g. $\mathrm{NO}_{3}{ }^{-}$and $\mathrm{SO}_{4}{ }^{2-}$ ). The application of alternate electron acceptors as bioremediation agents has been recently evaluated in a wetland environment contaminated with a weathered Arabian Light crude oil [42]. Three treatment strategies, inorganic nutrient addition $(\mathrm{N})$, inorganic nutrient addition plus nitrate as an alternate electron acceptor $(\mathrm{N}+\mathrm{N})$, and a no action control, were evaluated by GC/MS analysis to identify changes in the rate and extent of petroleum biodegradation. Preliminary results showed that the $\mathrm{N}$ and $\mathrm{N}+\mathrm{N}$ treatments enhanced intrinsic oil biodegradation rates. Between the nutrient treatments, there was only limited enhancement due to the addition of the alternate electron acceptor. Nutrient treatments did little to affect the extent of degradation. By 140 days, the two enhancement treatments resulted in nearly the same extent of removal as the control treatment (intrinsic bioremediation). Although these results were not the most promising, further studies at sites with lower rates of intrinsic oil-biodegradation activity are warranted. 


\section{Phytoremediation}

Saltmarshes are among the most sensitive of ecosystems, and the most difficult to clean. Application of traditional oil spill cleanup techniques within this habitat may cause more damage than the oil, itself. For example, foot and mechanical traffic will damage vegetation and drive the hydrocarbons into the anaerobic layer of the sediments where petroleum hydrocarbons may persist for decades [43]. Consideration is now being given to the inherent capacity of wetland plant species to aerate the soil rhizospheres as a means to stimulate aerobic oil biodegradation. Plants may also take up oil and release exudates and enzymes that stimulate microbial activity. While it has not been used as a marine oil spill countermeasure, this process described as phytoremediation, has been used in terrestrial environments for the cleanup of hazardous wastes [44], including polycyclic aromatic hydrocarbons [45].

\section{Surf-washing (enhanced oil-mineral fine interactions)}

Research studies following the Exxon Valdez oil spill demonstrated the significance of clay-oil flocculation processes on the natural cleansing of oil residues from impacted shoreline sediments [46]. Physical/ chemical interactions between oil and mineral fines reduce the adhesion of oil to solid surfaces to promote the formation of stable microsized oil droplets that are subsequently dispersed into the water column. By increasing the oil-water interface, i.e. the oil becomes more accessible to nutrients, oxygen and bacteria; this process enhances the rate and extent of oil biodegradation $[47,48]$. Thus, surf-washing operations to accelerate the interaction between oil and mineral fines can be considered a bioremediation strategy.

\section{Application and validation during spill response operations}

There have been several spill incidents in which bioremediation agents/strategies have been used to cleanup residual oil stranded within coastal environments. Representative marine vessel or site incidents include the Amoco Cadiz [49], the Apex Barge [50], the Mega Borg [51]; Prall's Island, New Jersey [52], and Seal Beach, California [52]. Bioremediation agents used at these sites included inorganic nutrients and microbial inocula. Unfortunately, it is difficult to validate the conclusions from many of these studies because of the logistical constraints imposed on the planning and execution of scientific programs after a major spill [10].

In terms of actual spill incidents, the most rigorous studies of bioremediation were those conducted by Exxon and the US Environmental Protection Agency (US EPA) as part of the Exxon Valdez spill cleanup operations. In this instance, bioremediation was adopted as a prime cleanup strategy. Following laboratory experiments which demonstrated the potential for bioremediation [5,53], laboratory and field experiments were conducted to evaluate the effectiveness of bioremediation agents that included an oleophilic fertilizer [7,15,54], dissolved water-soluble [5,54] and slow-release inorganic fertilizer formulations [5,7,31], and microbial inocula [21]. By measuring changes over time in the oil composition, relative to hopane, a stable high-molecular weight hydrocarbon present in the oil when spilled, the rate and extent of oil biodegradation was quantified with a high level of statistical confidence. Monitoring hydrocarbon losses relative to this conserved biomarker provided benchmark confirmation of oil biodegradation. Fertilizer additions were reported to accelerate the rate of oil removal by a factor of five or more. Furthermore, it was proven that the rate of oil biodegradation was a function of the nitrogen concentration maintained in the pore water of the intertidal sediments [7]. These results suggested that the effectiveness of bioremediation can be improved by making real-time measurements of nutrient levels in sediments to ensure that adequate, but safe, levels of nutrients are maintained during treatment.

In 1996, the Sea Empress grounded at the entrance of Milford Haven, United Kingdom spilling approximately 65000 tons of Forties Blend crude oil. Preliminary surveys identified several sand-gravel beaches where bioremediation treatment was considered appropriate since they had little tide and wave energy exposure. The residual oil was biodegradable, nutrient concentrations were limiting, and oxygen was present in sufficient quantities [55]. An experiment is currently being conducted on a beach in Bullwell Bay, which was impacted by oil emulsion. Preliminary results show that after only 8 weeks of experimentation, the spraying of sodium nitrate and potassium dihydrogen phosphate dissolved in seawater and/or the addition of the slow-release fertilizer Osmocote ${ }^{\circledR}$, effectively stimulated oil biodegradation rates above that of the control (Richard Swannell, personal communication). 


\section{OPERATIONAL GUIDELINES}

The decision to use bioremediation requires the demonstration of efficacy, reliability, and predictability. Despite the successful demonstration of its efficacy during the Exxon Valdez cleanup operations [6,7] and numerous experimental field trials $[8,9,56]$, bioremediation is still a controversial oil spill countermeasure and justification for its application is still assessed on a case by case basis, beginning with feasibility studies.

Part of the problem is that the guidelines for the proper use of the various bioremediation strategies in the marine environment are limited [10,57]. To make informed decisions on the applicability and usage of bioremediation, spill on-site coordinators require additional information on: (i) the testing and selection of bioremediation agents; (ii) toxicity and other environmental impacts; (iii) the influence of oil chemistry and environmental factors; and (iv) the monitoring of efficacy and operational endpoints.

\section{Testing and selection of bioremediation agents}

To assist response personnel in the selection and use of spill bioremediation agents, it is useful to have some simple, standard methods for screening performance and toxicity of bioremediation products becoming available [57,58]. In the United States, the US EPA, in cooperation with the National Environmental Technology Applications Center (NETAC) has developed standard test protocols for determining the effectiveness and toxicity of bioremediation agents [57]. The protocols consist of five progressive tiers of information and data gathering activity under which standard efficacy data would be generated early in the process of evaluating a particular agent and more ecosystem-specific efficacy data would be generated later in the process. The cost and complexities involved in generating data and the amount of data generated generally increase with each successive tier.

The approach begins with a Base Tier that emphasizes the assembling of basic information on the agent's toxicity based on a review of its formulation. During this tier, the presence of chemicals or biological components that are normally considered unacceptable (i.e. pathogens, carcinogens or hazardous substances) would be identified. Tier I provides the basis for a preliminary evaluation of whether an agent could be effectively and safely applied. Tier II provides empirical evidence through the use of shaker flask studies to estimate a product's effectiveness and toxicity. This tier also provides information on the relative changes in aliphatic and aromatic oil constituent concentrations over time and the total hydrocarbon degrading microbial activity. Tier III proposes the usage of microcosm systems that simulate important environmental scenarios (open water, marshes, etc.). Tier IV proposes the use of field demonstrations (spills-of-opportunity or preplanned controlled spills) to predict a product's potential effectiveness in the natural environment.

There is no doubt about the utility of shaker flask studies. In addition to fulfilling regulatory compliance needs [53], they have been used to rank the efficacy of available products [14,58], and to identify the advantages and disadvantages of various forms of nutrients [59]. However, they are not meant to simulate the natural environment where conditions are in a constant state of flux with respect to tidal cycles and washout, temperature variation, climatic changes, freshwater/saltwater interactions, etc. [14]. Indeed, the limitations of the shaker flask and mesocosm tests were recently demonstrated [8]. The results of the shaker flask and mesocosm tests with a commercial bioremediation agent (listed in the current National Contingency Plan (NCP) Product Schedule), containing mineral nutrients and nonpathogenic bacteria, were not achieved under field conditions. In this case, the oleophilic product suppressed both the rate and extent of oil loss by tidal activity and biodegradation, as its application increased the retention of residual oil within the sediments by altering its physical/chemical characteristics.

The need for controlled-release field experiments is self-evident. Advantages include the design of statistically valid, replicated, randomized block experiments with a variety of experimental treatments under conditions that allow one to address issues such as site heterogeneity, and both biotic and abiotic loss mechanisms.

To date, different methods have been used to test the efficacy of bioremediation agents in the field. An international working group has been established to define a common experimental protocol to evaluate the effectiveness of bioremediation procedures in field trials [60]. The usage of a standard protocol will 
enable various laboratories to compare the results of experiments conducted in different environments [61-63]. Such coordinated efforts by the scientific community will accelerate the development of an operational guideline based on a consolidated scientific database, containing data collected under different environmental conditions.

\section{Toxicity and other environmental impacts}

Bioremediation strategies based on nutrient enrichment have generally received a positive response from the public since its implicit goal is that of reducing toxic effects by converting organic molecules to cell biomass and products, such as carbon dioxide and water, which are readily accommodated in the environment $[64,65]$. It is generally thought that bioremediation can be applied without hazard to the environment, provided that the toxicity of the products have been identified, and the applications are maintained within approved safety limits. Nevertheless, environmentalists have expressed concern about its net benefit because of the potential production of toxic metabolic by-products, toxic components within the formulation of bioremediation agents, and the ineffective degradation of the most toxic components within residual oils $[52,66]$. To date, detrimental effects from bioremediation by nutrient enrichment have not been observed following actual field operations [6,67]. However, the possibility of a future incident does exist. For example, oxygen depletion and production of ammonia from excessive applications of a fish-bone meal fertilizer during a field study caused detrimental effects that included toxicity and the suppression of oil degradation rates [68]. For safety assurance, future operational guidelines will incorporate protocols for ecotoxicological monitoring.

Stable carbon $\left(\delta^{13} \mathrm{C}\right)$ and nitrogen $\left(\delta^{15} \mathrm{~N}\right)$ isotopes have been used to monitor changes in trophic interactions following the application of bioremediation agents in the cleanup of oil residues from the Exxon Valdez spill [69]. No evidence was found for the transfer of oil-carbon or fertilizer-nitrogen assimilated by bacteria to higher trophic levels. Assuming bioremediation was effective, the excess bacterial biomass formed from oil degradation was either not transferred efficiently to higher trophic levels or transported from the beach to coastal waters by the tide.

\section{The influence of oil chemistry and environmental factors}

A fraction of the components in crude oils spilled within the marine environment are easily degraded; others are more slowly and/or less completely degraded; and some compounds are totally nonbiodegradable (recalcitrant). As a guideline, the greater the complexity of the hydrocarbon structure (i.e. the higher number of alkyl-branched substituents or condensed aromatic rings), the slower the rates of degradation and the greater the likelihood of accumulating partially oxidized intermediary metabolites. These factors, as well as others such as volatility, set the practical operational limits for the application of bioremediation strategies. For example, there is no net advantage to bioremediate a spill of light hydrocarbons such as gasoline, since it would evaporate rapidly.

A detailed 7-month study on the bioremediation of a waxy crude oil in sand beach and salt marsh environments has demonstrated the influence of environmental factors on the outcome of a bioremediation treatment strategy [34]. Terra Nova crude oil was added at two concentrations $3 \%(\mathrm{v} / \mathrm{v})$ and $0.3 \%(\mathrm{v} / \mathrm{v})$ to sand beach and salt marsh sediments retained in in situ enclosures. Bioremediation treatment for the oiled sediments consisted of semicontinuous applications of an inorganic agricultural fertilizer formulation. At the lower oil concentrations $(0.3 \%)$ within the sand beach environment, oil biodegradation proceeded rapidly in both the fertilized plot and the unfertilized control. The application of a bioremediation treatment provided no advantage. However, at the higher oil concentrations (3\%) on the sandy beach, oil biodegradation rates appeared to be nutrient limited since the bioremediation treatments promoted chemical changes in oil composition consistent with that of enhanced biodegradation. Furthermore, additions of the fertilizer at a higher dosage rate did not enhance the biodegradation rates within the sandy beach sediments. In contrast, the addition of nutrients to the salt marsh sediments containing the lower $(0.3 \%)$ oil concentration resulted in enhanced rates of biodegradation. This additional need for nutrients at the lower oil concentrations is consistent with the notion that nutrient demands within a salt marsh environment are higher, due to the size of the microbial population within an organic-carbon rich environment. At the higher oil concentration (3\%) within the 
salt marsh sediments, insignificant rates of oil degradation were reported following fertilization. The results clearly demonstrated that the success of bioremediation depends on the nature of the contaminated shoreline. On the sandy beach with low concentrations of oil, toxicity to the oil-degrading bacteria was not a factor, and ambient nitrogen and phosphorus were sufficient to result in rapid oil biodegradation. Under these conditions, nutrient enrichment appears to provide little or no benefit and nature can be left to take its course (a nonaction strategy). However, at higher oil levels (i.e. a carbon-enriched environment), the microbial community within the sand beach became nutrient-limited, and bioremediation treatment could effectively enhance the rate of oil removal. In the salt marsh environment treated with similar oil concentrations, oil penetrated into the anoxic layers of the sediment and the fertilization strategy was ineffective. In this specific case, the addition of oxygen may be required as a part of the bioremediation strategy. The intricacy of interactions shown to influence the success of bioremediation in this study is not unique. Within the sediments of Prince William Sound, Alaska [70], the ability of the indigenous microbial population to mineralize hexadecane, phenanthrene, and naphthalene, has been shown to be influenced by the intensity of physical mixing, the method of bioremediation agent application, and the availability of alternative carbon sources.

The efficacy of specific bioremediation formulations may be influenced by environmental conditions. For example, at temperate conditions above $15^{\circ} \mathrm{C}$, slow-release (sulfur-coated urea) fertilizer formulations appear to be more effective in retaining elevated nutrient concentrations within the sediments than inorganic nitrogen (ammonium nitrate) fertilizers [35]. Lower temperatures are thought to reduce the permeability of the coating on the slow-release fertilizer, effectively suppressing nutrient release rates. For optimal effectiveness, the selection of bioremediation agents should take into account the environmental conditions, the type of contaminated shoreline, and the methods of application $[6,10,35,71,72]$.

The transport of water-soluble nutrients in the intertidal region of sandy beaches has been studied with lithium as a conservative tracer [73-75]. These studies demonstrated that dissolved nutrient transport in sandy beaches is driven by tide-influenced hydraulic gradients and wave activity. In the intertidal region, washout of water-soluble nutrients from the bioremediation zone of a sand beach in Delaware was rapid enough to require daily reapplication of fertilizer [75]. Submergence by tide alone or by tide plus waves was sufficient to reduce the tracer concentration in the bioremediation zone by greater than $90 \%$. These results suggest that nutrient retention in the bioremediation zone of a sand beach can be predicted from data on the extent of water coverage.

In terms of the microbiota in a north-temperate environment, although winter temperatures did not affect the numbers of heterotrophic bacteria in oiled sediments within experimental enclosures, the numbers of oil-degraders declined [33]. This effect of low seasonal temperatures suppressing the growth of oil-degrading bacteria within oil-contaminated sediments has been observed in subsequent studies $[6,34,56]$. Further study is warranted to identify if these observations are attributed to a physiological response or to physical/chemical changes in the oil that alters its availability to the bacteria. It is now also apparent that the most important influence on the carrying capacity for hydrocarbon degraders in the marine environment may be the removal of biomass by physical processes, such as scouring by breaking waves. If this is the case, indigenous bacteria will grow to their carrying capacity provided that sufficient nutrients are present. The addition of exogeneous hydrocarbon degraders (i.e. bioaugmentation) will not succeed in increasing population density [9].

Biodegradation of crude oil stranded within intertidal environments can take place rapidly under temperate conditions. In a recent field trial on the coast of Delaware, natural nitrogen concentrations were found to be high enough to sustain rapid intrinsic rates of biodegradation without human intervention [9]. Although biostimulation with an exogenous source of inorganic mineral nutrients at this site significantly accelerated the rate of hydrocarbon biodegradation, the incremental increase in biodegradation rate over the intrinsic rate (i.e. slightly greater than twofold for the alkanes and 50\% for the PAHs) would not be high enough to warrant a recommendation to actively initiate a major, perhaps costly, bioremediation action in the event of a large crude oil spill in that area. A similar conclusion was also reached in a field trial to evaluate the influence of a slow-release fertilizer on the biodegradation rate of crude oil spilled on interstitial sediments of an estuary [76,77]. Due to adaptation of marine bacteria to hydrocarbons along the coast of Brittany [65] and high background levels of $\mathrm{N}$ and $\mathrm{P}$ at the study site, no significant difference 
in biodegradation rates was detected following nutrient addition. It was proposed that bioremediation by nutrient enrichment would be of limited use if background interstitial porewater levels of $\mathrm{N}$ exceed 100 $\mu$ moles/L. A strong correlation between the available concentrations of ammonia and phosphorus and the degradation rates of petroleum has been demonstrated in a recent study in Texas to monitor the natural recovery of an oil impacted coastal wetland environment by intrinsic biodegradation [78]. In light of these results, in the event of a catastrophic oil spill impacting a shoreline, it is suggested that nutrient levels within the interstitial waters be determined before any decision is made to apply bioremediation agents.

\section{Monitoring of efficacy and operational endpoints}

The acceptance and use of bioremediation strategies has been limited by the lack of defined performance standards. For proper application of the technology, there is a need for monitoring programs to demonstrate efficacy and to identify operational endpoints.

A major problem is the intrinsic heterogeneity of the natural environment. Absolute levels of contamination can vary widely over a site and simple estimates of biodegradation based on sequential samples can be confounded by this heterogeneity, unless large numbers of samples are taken. However, this problem can be resolved by the normalization of data to conserved markers such as hopanes and chrysenes found within the oil $[8,9,77,79]$. These costly and time-consuming analyses by gas chromatography/mass spectrometry (GC/MS) are necessary to demonstrate effectiveness at a level of precision and accuracy demanded by the scientific community. However, from an operational perspective, considering the numbers of samples needed to characterize a spill site, other more rapid and less costly performance measures must be developed to satisfy regulators and the responsible party managers.

In situ measurement of microbial $\mathrm{CO}_{2}$ production by the use of respirometers or radiotracer methods can be used to quantify oil mineralization rates to estimate bioremediation success [56,80]. Enumeration of potential oil-degrading bacteria by isolation on specific media has become a benchmark in many bioremediation studies although many bacteria within the natural environment are dormant or unculturable. Therefore, it is essential to show, by combined chemical and microbiological methods, that the oil-degrading bacteria are, in fact, active.

Recent studies have shown that the distribution of the genes for hydrocarbon degradation change in response to the composition of the hydrocarbons in the environment to which the bacterial populations are exposed [81]. Future use of DNA and RNA gene probes for pollutant catabolic pathways may provide practical and evolutionary insights about how and why biodegradation activity is controlled and expressed [82,83].

As discussed, future operational guidelines will incorporate reliable ecotoxicological monitoring programs to document their efficacy for toxicity reduction. In addition to direct chemical evidence of oil degradation, microscale biotests may provide an operational endpoint indicator for bioremediation activities on the basis of toxicity reduction, i.e. the site is acceptable as there is no detectable toxic effects, or the treatment is detrimental $[68,84]$.

\section{CONCLUSION}

With the recent demonstrations of its efficacy in the field, bioremediation has been touted as the emerging oil spill countermeasure of the 1990s. However, it should not be used indiscriminately, in isolation from other procedures, or without adequate knowledge of the specific environment in which it is to be employed. For example, current bioremediation strategies would not be recommended for the removal of bulk free-oil on the surface of sediments since more effective mechanical cleanup technologies exist. Furthermore, a practical bioremediation strategy has not been developed for the treatment of spills in the open ocean. However, operational limitations exist for all oil spill countermeasures. In the context of shoreline cleanup, bioremediation should be considered a useful addition to our toolbox of oil spill treatment strategies, including the option of 'no treatment'. As outlined in this review, appropriate protocols are being developed for the evaluation and application of bioremediation agents. Field programs evaluating the effectiveness of nutrient formulations have shown the need to design bioremediation treatments specific to the environmental conditions present at the site in question. Pre-treatment 
assessments are recommended to determine if bioremediation is a viable response option, and if so, the strategy of choice. The database for decision making should include information on the type of oil, application methodologies available (form and type of bioremediation agent, type and frequency of application), environmental conditions (availability of nutrients, bacteria, oxygen, temperature, and wave/tidal immersion), as well as the time available for cleanup. A monitoring program must be implemented to validate that the treatment is effective and not detrimental to the environment. Termination of treatment should be considered if and when: (i) it is no longer or not effective; (ii) the oil has degraded to acceptable concentrations (e.g. a concentration that has no biological effect); or (iii) toxicity is shown to be on the increase.

\section{ACKNOWLEDGEMENTS}

Financial support for the preparation of this manuscript was provided by the Toxic Chemicals Program of Fisheries and Oceans, Canada and the interdepartmental Panel on Energy Research and Development (PERD), Canada.

\section{REFERENCES}

1 C. E. Zobell. Adv. Water Pollut. Res. 3, 85 (1964).

2 C. E. Cerniglia. Curr. Opin. Biotechnol. 4, 331 (1993).

3 D. T. Gibson, V. Subramanian. Microbial Degradation of Organic Compounds (D. T. Gibson, ed.), pp. 181252. Marcel Dekker (1984).

4 R. M. Atlas, R. Bartha. Adv. Microb. Ecol. 12, 287 (1992).

5 P. H. Pritchard, C. F. Costa. Environ. Sci. Technol. 25, 372 (1991).

6 R. C. Prince. Crit. Rev. Microbiol. 19, 217 (1993).

7 J. R. Bragg, R. C. Prince, E. J. Harner, R. M. Atlas. Nature 368, 413 (1994).

8 K. Lee, G. H. Tremblay, J. Gauthier, S. E. Cobanli, M. Griffin. In Proc. 1997 Int. Oil Spill Conference, pp. 697704. American Petroleum Institute, Washington, DC (1997).

9 A. D. Venosa, M. T. Suidan, B. A. Wrenn, K. L. Strohmeier, J. R. Haines, B. L. Eberhart, D. King, E. L. Holder. Environ. Sci. Technol. 30, 1764 (1996).

10 R. P. J. Swannell, K. Lee, M. McDonagh. Microbiol. Rev. 60, 342 (1996).

11 R. Hoff. Mar. Pollut. Bull. 26, 476 (1993).

12 R. P. J. Swannell, I. M. Head. Nature 368, 396 (1994).

13 K. Lee, E. M. Levy. In Proc. 1987 Int. Oil Spill Conference, pp. 411-416. American Petroleum Institute, Washington, DC (1987).

14 A. D. Venosa, J. R. Haines, B. L. Eberhart. Methods in Biotechnology, Vol. 2: Bioremediation Protocols (D. Sheehan, ed.), pp. 47-58. Humana Press Inc, Totowa, NJ (1997).

15 D. K. Button, B. R. Robertson, D. McIntosh, F. Juttner. Appl. Environ. Microbiol. 58, 243 (1992).

16 R. M. Atlas. Oceanus 36, 71 (1993).

17 R. H. Pierce, A. M. Cundell, R.W. Traxler. Appl. Microbiol. 29, 646.

18 D. Delille, A. Basseres, A. Dessommes. Microb. Ecol. 33, 97 (1997).

19 N. M. Fayad, R. L. Edora, A. H. El-Mubarak, A. B. Polancos. Bull. Environ. Contam. Toxicol. 49, 787 (1992).

20 A. D. Venosa, J. R. Haines, W. Nisamaneepong, R. Govind, S. Pradhan, B. Siddique. J. Hazard. Mat. 28, 131 (1991).

21 A. D. Venosa, J. R. Haines, W. Nisamaneepong, R. Govind, S. Pradhan, B. Siddique. J. Ind. Microbiol. 10, 13 (1992).

22 G. Lethbridge, H. J. J. Vits, R. J. Watkinson. Nature. 371, 97 (1994).

23 A. D. Wong, C. D. Goldsmith. Water Sci. Technol. 20, 131 (1988).

24 K. Lee, E. M. Levy. Aquatic Toxicology and Water Quality Management (J. A. Nriagu, J. S. S. Lakshminarayana, eds), pp. 217-243. J. Wiley \& Sons Inc., USA (1989).

25 R. M. Atlas, R. Bartha. Environ. Sci. Technol. 7, 538 (1973). 
26 R. M. Atlas, R. Bartha. Biotechol. Bioeng. 14, 309 (1972).

27 J. D. Walker, R. R. Colwell, L. Petrakis. Can J. Microbiol. 22, 1209 (1976).

28 A. L. Bridie, J. Bos. Inst. Petrol. 57, 270 (1971).

29 B. Tramier, A. Sirvins. In Proc. 1983 Oil Spill Conference, pp. 115-119. American Petroleum Institute, Washington, DC (1983).

30 P. Sveum, A. Ladousse. In Proc. 1989 Int. Oil Spill Conference, pp. 439-446. American Petroleum Institute, Washington, DC (1989).

31 S. I. Safferman. In Proc. 1991 Int. Oil Spill Conference, pp. 571-576. American Petroleum Institute, Washington, DC (1991).

32 US EPA. Interim report: oil spill bioremediation project, p. 220. Office of Research and Development, US Environmental Protection Agency: Gulf Breeze, FL (1990).

33 K. Lee, E. M. Levy. In Proc. 1989 Int. Oil Spill Conference, pp. 479-486. American Petroleum Institute, Washington, DC (1989).

34 K. Lee, E. M. Levy. In Proc. 1991 Int. Oil Spill Conference, pp. 541-547. American Petroleum Institute, Washington, DC (1991).

35 K. Lee, G. H. Tremblay, E. M. Levy. In Proc. 1993 Int. Oil Spill Conference, pp. 449-454. American Petroleum Institute, Washington, DC (1993).

36 A. Ladousse, B. Tramier. In Proc. 1991 Oil Spill Conference, pp. 577-581. American Petroleum Institute, Washington, DC (1991).

37 A. Basseres, P. Eyraud, A. Ladousse, B. Tramier. In Proc. 1993 Int. Oil Spill Conference, pp. $495-501$. American Petroleum Institute, Washington, DC (1993).

38 K. Lee, G. H. Tremblay, S. E. Cobanli. In Proc. 1995 Int. Oil Spill Conference, pp. 107-113. American Petroleum Institute, Washington, DC (1995).

39 E. Sendstad, P. Sveum, L. J. Endal, Y. Brattbakk, O. Ronning. In Proc. 7th Arctic and Marine Oilspill Program (AMOP) Technical Seminar, pp. 60-74. Environment Canada (1984).

40 W. H. Patrick, D. S. Mikkelsen, B. R. Wells. In Fertilizer Technology and Use, pp. 197-228. Soil Science Society of Maerica, Madison (1985).

41 I. Valiela. Marine Ecological Processes, Springer-Verlag, New York (1984).

42 M. A. Mills, J. S. Bonner, T. J. McDonald, R. L. Autenrieth. In Proc. Of 4th Intl In Situ on-Site Bioreclaimation Symposium 3, 355-360 (1997).

43 J. M. Baker, L. M. Guzman, P. D. Bartlett, D. I. Little, C. M. Wilson. In Proc. 1993 Int. Oil Spill Conference, pp. 395-399. American Petroleum Institute, Washington, DC (1993).

44 J. L. Schnoor, L. A. Licht, S. C. McCutcheon, N. L. Wolfe, L. H. Carreira. Env. Sci. Technol. 29, 318 (1995).

45 K. M. Banks, A. P. Schwab. In Symposium on bioremediation of hazardous wastes: research, development and field evaluations, Washington, DC, Environmental Protection Agency, EPA/600/R-93/054, 246 (1993).

46 J. R. Bragg, E. H. Owens. In Proc. 17th Arctic and Marine Oil Spill Program (AMOP) Technical Seminar, pp. 1-24. Vancouver, BC, Canada (1994).

47 K. Lee, T. Lunel, P. Wood, R. Swannell, P. Stoffyn-Egli. In Proc. 1997 Int. Oil Spill Conference, pp. $235-240$. American Petroleum Institute, Washington, DC (1997).

48 K. Lee, S. St. Pierre, A. M. Weise. In Proc. 20th Arctic and Marine Oilspill Program (AMOP) Technical Seminar, pp. 715-722. Environment Canada (1997).

49 C. Bocard, P. Renault, J. Croquette. In Proc. 1979 Int. Oil Spill Conference, pp. 449-454. American Petroleum Institute, Washington, DC (1979).

50 R. Nadeau, R. Singhvi, J. Ryabik, Y. H. Lin, J. Syslo. In Proc. 15th Arctic and Marine Oilspill Program (AMOP) Technical Seminar, pp. 739-756. Environment Canada (1992).

51 Texas General Land Office. Mega Borg Oil Spill off the Texas Coast: A Report on the Effect of Bioremediation. Texas General Land Office, Texas Water Commission, Austin, Texas (1990).

52 R. Hoff. Report HMRB 91-2. National Oceanic and Atmospheric Administration, Washington, DC (1991).

53 P. H. Pritchard, J. G. Mueller, J. C. Rogers, F. V. Kremer, J. A. Glaser. Bioremediation. 3, 315 (1992).

54 J. A. Glaser, A. D. Venosa, J. Opatken. In Proc. 1991 Int. Oil Spill Conference, pp. 559-562. American Petroleum Institute, Washington, DC (1991). 
55 T. Lunel, R. P. J. Swannell, J. Rusin, P. Wood, N. Bailey, C. Halliwell, L. Davies, M. Sommerville, A. Dobie, D. Mitchell, M. McDonagh, K. Lee. Spill Sci. Technol. 2, 99 (1995).

56 R. P. J. Swannell, D. J. Mitchell, D. M. Jones, A. L. Willis, K. Lee, J. E. Lepo. In Proc. 4th Int In Situ on-Site Bioreclaimation Symposium. 4, 401-406 (1997).

57 G. Thomas, R. Nadeau, J. Ryabik. Proceedings 2nd International Oil Spill Research and Development Forum, pp. 56-62. International Maritime Organization, London, UK (1995).

58 S. Blenkinsopp, G. Sergy, Z. Wang, M. F. Fingas, J. Foght, D. W. S. Westlake. In Proc. 1995 Int. Oil Spill Conference, pp. 91-96. American Petroleum Institute, Washington, DC (1995).

59 B. A. Wrenn, J. R. Haines, A. D. Venosa, M. Kadhodayan, M. T. Suidan. J. Ind. Microbiol. 13, 279 (1994).

60 F. X. Merlin. In Proc. 2nd Internat. Oil Spill Research and Development Forum. 1, 37-44. International Maritime Organization, London, United Kingdom (1995).

61 F. X. Merlin, K. Lee, R. P. J. Swannell, J. Oudot, A. Basseres, T. Reilly, C. Chaumery, C. Dalmazzone, P. Sveum. In Proc. 17th Arctic and Marine Oil Spill Program (AMOP) Technical Seminar, pp. 465-478. Environment Canada (1994).

62 K. Lee, F. X. Merlin, R. P. J. Swannell, T. Reilly, P. Sveum, J. Oudot, M. Guillerme, J. Ducreuz, C. Chaumery. In Proc. 1995 Int. Oil Spill Conference, pp. 901-902. American Petroleum Institute, Washington, DC (1995).

63 S. LeFloch, F. X. Merlin, M. Guillerme, P. Tozzolino, D. Ballerini, C. Dalmazzone, T. Lundh. In Proceedings of the 4th International In Situ and On-site Bioreclaimation Symposium, pp. 411-417 (1997).

64 R. M. Atlas, D. Pramer. ASM News. 56, 7 (1990).

65 R. M. Atlas, C. E. Cerniglia. Bioscience. 45, 332 (1995).

66 US Congress (Office of Technology Assessment). Bioremediation of Marine Oil Spills-Background Paper, p. 31. OTA-BP-0-70, US Government Printing Office, Washington, DC (1991).

67 A. J. Mearns, A. D. Venosa, K. Lee, M. Salazar. In Proc. 1997 Int. Oil Spill Conference, pp. 707-712. American Petroleum Institute, Washington, DC (1997).

68 K. Lee, R. Siron, G. H. Tremblay. Microbial Processes for Bioremediation (R. E. Hinchee, F. J. Brockman, C. M. Vogel, eds), pp. 117-128. Battelle Press, Columbus, OH (1995).

69 R. B. Coffin, L. A. Cifuentes, P. H. Pritchard. Mar. Environ. Res. 44, 27 (1997).

70 S. F. Sugai, J. E. Lindstrom, J. F. Braddock. Environ. Sci. Technol. 31, 1564 (1997).

71 R. P. J. Swannell, B. C. Croft, A. L. Grant, K. Lee. Spill Sci. Technol. 2, 151 (1995).

72 R. P. J. Swannell, D. J. Mitchell, D. M. Jones, A. L. Willis, K. Lee, J. E. Lepo. In Proc. 20th Arctic and Marine Oilspill Program (AMOP) Technical Seminar, pp. 703-713. Environment Canada (1997).

73 B. A. Wrenn, M. C. Boufadel, M. T. Suidan, A. D. Venosa. In Proc. 4th Int In Situ on-Site Bioreclaimation Symposium. 4, 267-272 (1997).

74 B. A. Wrenn, M. T. Suidan, K. L. Strohmeier, B. L. Eberhardt, G. J. Wilson, A. D. Venosa. Wat. Res. 31, 515 (1997).

75 B. A. Wrenn, M. T. Suidan, K. L. Strohmeier, B. L. Eberhardt, G. J. Wilson, A. D. Venosa. Proc. 1995 Int. Oil Spill Conference, pp. 896-897. American Petroleum Institute, Washington, DC (1995).

76 F. X. Merlin, A. Basseres, C. Chaumery, C. Palmamazzoue, J. Ducreux, K. Lee, J. Oudot, T. Reilly, R. P. J. Swannell. Report R. 95.38.1C, CEDRE, Brest (1995).

77 J. Oudot, F. X. Merlin, P. Pinvidic. Mar. Environ. Res. (1997), in press.

78 B. C. Harris, J. S. Bonner, R. L. Autenrieth. In Proc. 20th Arctic and Marine Oilspill Program (AMOP) Technical Seminar, pp. 685-692. Environment Canada (1997).

79 R. C. Prince, E. N. Drake, P. C. Madden, G. S. Douglas. In Polycyclic Aromatic Hydrocarbons, in-Situ on-Site Bioremediation. 2, 205-210 (1993).

80 R. P. J. Swannell, A. Basseres, K. Lee, F. X. Merlin. In Proc. 17th Arctic and Marine Oilspill Program (AMOP) Technical Seminar, pp. 1273-1286. Environment Canada (1994).

81 J. B. Sotsky, C. W. Greer, R. M. Atlas. Can. J. Microbiol. 40, 981 (1994).

82 G. S. Sayler, A. C. Layton. Ann. Rev. Microbiol. 44, 625 (1990).

83 C. L. Greer, Y. Masson, R. Comeau, Brousseau, R. Samson. Water Pollut. Res. J. Canada. 28, 275 (1993).

84 A. J. Mearns, K. Doe, W. Fisher, R. Hoff, K. Lee, R. Siron, C. Mueller, A. Venosa. In Proc. 18th Arctic and Marine Oilspill Program (AMOP) Technical Seminar, pp. 1133-1145. Environment Canada (1995). 